\title{
一般用医薬品とセルフメディケーションに関する薬学教育の特徵と課題
}

\author{
渡辺謹三
}

\section{Non-prescription Drugs and Self-medication: Features and Subjects in Pharmaceutical Education}

\author{
Kinzo Watanabe \\ School of Pharmacy, Tokyo University of Pharmacy and Life Sciences; \\ 1432-1 Horinouchi, Hachioji, Tokyo 192-0392, Japan.
}

(Received September 13, 2015)

\begin{abstract}
At the time of consultation with a patient regarding OTC drugs, a pharmacist goes through the following five steps. In Step 1 information is collected, including the patient's gender, age, health condition, living situation, etc. In Step 2, upon analyzing and evaluating this collected information, the pharmacist decides whether to recommend that the patient see a medical doctor or whether an OTC drug is sufficient. In Step 3, when an OTC drug is required, the pharmacist suggests the most suitable OTC drug. In Step 4, the pharmacist provides the patient recommendations and information about the selected OTC. In Step 5, sales record entry and aftercare are performed. In these five steps, the pharmacist is making a decision on whether the consultation recommendation is required or optional; the step of making an optimal selection of an OTC drug is distinct from prescription dispensing. In many cases, at the time of OTC drug consultation, since the patient is not consulting a medical doctor, a pharmacist becomes a "first access" health professional. In this instance, the advice of a pharmacist may have a great influence on a patient's prognosis regarding the particular health challenge. Therefore, pharmacists who perform patient consultations regarding OTC drugs are required to have broad medical knowledge and communication skills. The features of consultation and information dissemination about OTC drugs by a pharmacist, and the practice and study of this subject in present-day pharmaceutical education, are described herein.
\end{abstract}

Key words - OTC drug; self-medication; pharmaceutical education; pharmacist consultation

1. はじめに

薬剤師が要指導医薬品や一般用医薬品（以下，要 指導医薬品と一般用医薬品をあわせて「OTC 医薬 品」と略記する）を販売したり，薬局製造販売医薬 品を製造販売することは，薬剤師法に定められた薬 剤師の任務のなかの「医薬品の供給」に相当する. とくに，薬局医薬品（薬局医薬品のうち薬局製造販 売医薬品は処方箋がなくても販売可能)，要指導医 薬品及び一般用医薬品のなかの第一類医薬品の販売 は薬剤師の専権事項で，わが国においてこれが許さ れているのは薬剤師のみである.

本稿では，薬学教育モデル・コアカリキュラムに おける薬剤師の OTC 医薬品販売とセルフメディ

東京薬科大学薬学部（１92-0392 東京都八王子市堀之 内 1432-1)

e-mail: kinzo@toyaku.ac.jp

本総説は, 日本薬学会第 135 年会シンポジウム S36 で 発表した内容を中心に記述したものである.
ケーションについての取扱いについて言及し, さら にこれらを薬学教育で取り組んで展開する際に課題 となる業務上の特徵を処方箋調剂業務の特徵などと 比較しながら述べてみたい.

2. 薬学教育モデル・コアカリキュラムにおける

OTC 医薬品とセルフメディケーション

平成 18 年度から薬剂師を目指す学生に対する薬 学教育は六年制に移行し，その学習過程の中に実務 に関係する内容が多く取り込まれた。しかしながら, OTC 医薬品の販売とセルフメディケーションなど に関する内容は，薬学部が六年制に移行した平成 18 年度から実施された当初の薬学教育モデル・コ アカリキュラム（以下「コアカリ」）において希薄 であった。 OTC 医薬品の販売に関係が深いコアカ リの行動目標 [specific behavioral objective (s); SBO (s) ] は, 「C18 薬学と社会」,「(3)コミュニティー ファーマシー」に「(2) 主な一般用医薬品（OTC 薬） を列挙し，使用目的を説明できる」と記してあるの 
みで, 1) 実務実習事前学習には OTC 医薬品の販売 に関する SBO が取り入れられていない。しかしな がら，薬局実務実習方略では「(4)薬局カウンター で学ぶ」に「セルフメディケーションのための一般 用医薬品, 医療用具, 健康食品などを適切に選択・ 供給できる。（技能）」，「疾病の予防及び健康管理に ついてアドバイスできる。（技能・態度）」，「医師へ の受診勧告を適切に行うことができる。（技能・態 度)」などの SBOs が記され, 約 50 名の顧客と対応 することとされている.11

平成 25 年度改訂版「薬学教育モデル・コアカリ キュラム」（以下「改訂コアカリ」）では，OTC 医 薬品に関係する取扱いが大幅に改訂された. ${ }^{2)}$

「平成 25 年度改訂版・薬学教育モデル・コアカリ キュラム改訂概要」2)には，「E 医療薬学」部分の改 訂について，「さらに，近年の薬剤師の役割の変化 を反映させ，「旧 C18 薬学と社会 (3) コミュニ ティファーマシー」の「OTC 薬・セルフメディケー ション」は薬理・病態・薬物治療に移動し, 内容を 充実させ，症候に関する知識を解釈のレベル（患者 情報をもとに疾患を推測できる）まで求めた」と記 載された。改訂コアカリ「E 臨床薬学」,「E2 薬理・ 病態・薬物治療」に 1 つのユニットとして取り入れ られた「(9) 要指導医薬品・一般用医薬品とセルフ メディケーション」に挙げられた 8 つ SBOs は以 下の通りである.

1. 地域における疾病予防, 健康維持増進, セル フメディケーションのために薬剤師が果たす役 割を概説できる.

2. 要指導医薬品および一般用医薬品（リスクの 程度に応じた区分（第一類，第二類，第三類） も含む）について説明し，各分類に含まれる代 表的な製剤を列挙できる.

3. 代表的な症候について，関連する頻度の高い 疾患，見逃してはいけない疾患を列挙できる。

4. 要指導医薬品・一般用医薬品の選択, 受診勧 奨の要否を判断するために必要な患者情報を収 集できる.（技能）

5. 以下の疾患・症候に対するセルフメディケー ションに用いる要指導医薬品・一般用医薬品等 に含まれる成分・作用・副作用を列挙できる. 発熱, 痛夕, かゆ夕, 消化器症状, 呼吸器症 状，アレルギー，細菌・真菌感染症，生活習慣

\section{病 等}

6. 主な養生法（運動・食事療法，サプリメン 卜，保健機能食品を含む）とその健康の保持 • 促進における意義を説明できる。

7. 要指導医薬品・一般用医薬品と医療用医薬 品, サプリメント，保健機能食品等との代表的 な相互作用を説明できる。

8. 要指導医薬品・一般用医薬品等による治療効 果と副作用を判定するための情報を収集し評価 できる.（技能）

「F 薬学臨床」においても「(5)地域の保健・医 療・福祉への参画」において,「【(3)プライマリケア・ セルフメディケーションの実践】」として上記の SBOs に対応する実務実習でのSBOs（実務実習履 修前に修得すべき事項を含む）が取り入れられてい る. また, 症状についての相談対応時に重要な症候 判断に関しても，前述の改訂概要に記されたように 一歩踏み込んだ内容の SBO となっている。これら 以外に，OTC 医薬品にしばしば配合される漢方薬 についても「E 臨床薬学」の「E2 薬理・病態・薬 物治療」に 1 つのユニットとして取り入れられてい る.

改訂コアカリ上のこのような変更に加えて，本誌 上シンポジウムの序文に記したように, 現在薬剤師 のセルフメディケーション支援に対する社会の要求 が高まっていることから, 今後薬学部において薬剤 師の OTC 医薬品販売時の相談対応を通したセルフ メディケーション支援については今まで以上に大き く取り扱わなければならなくなるものと考えられる.

3. OTC 医薬品とセルフメディケーションに関 する相談対応の特徵

薬局における薬剤師の処方箋調剤業務と OTC 医 薬品販売時の相談対応業務はかなり異なっている. 現在，薬学教育における薬局業務の教育は処方調剂 業務を中心に行われているが，今後，OTC 医薬品

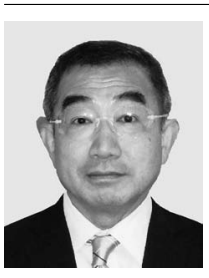

渡辺謹三
東京薬科大学薬学部一般用医薬品学教 室（佐藤幸吉記念教室）教授。1952 年 4 月生. 生家が薬局で幼児期から OTC 医薬品に囲まれて生活していた。1975 年東京薬科大学卒業, 1980 年同大学院 修了 (薬学博士). 同生命科学部准教授 などを経て現職に就く間に約 5 年の一 般用医薬品販売，処方調剂などの実務 経験がある。 


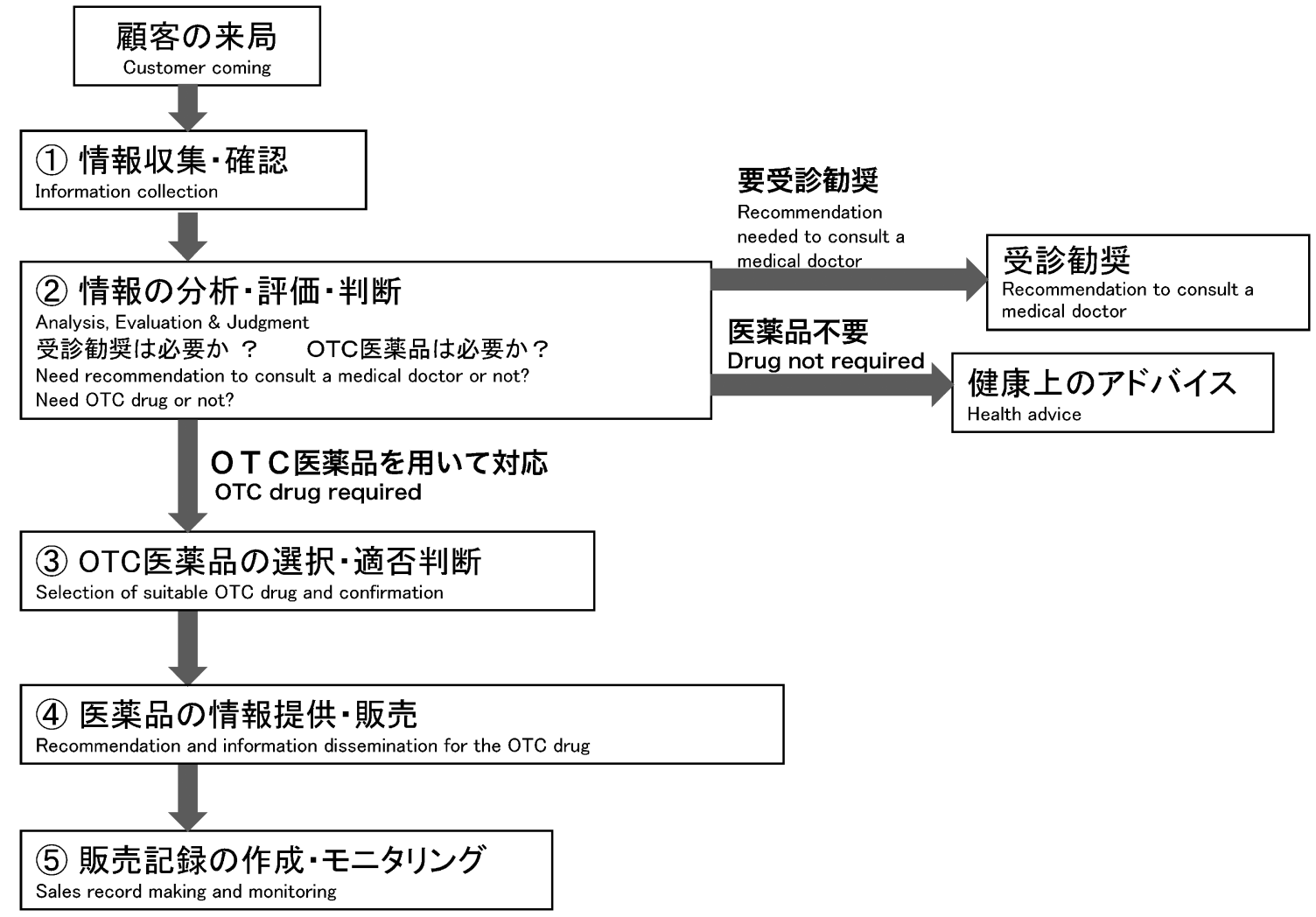

Fig. 1 Five Steps of Consultation with a Patient on OTC Drugs by a Pharmacist

販売時の相談対応業務に取り組む際には，この業務 に独特ないくつかの課題に直面することになる。 そ こで, 薬学教育で取り組む際に課題となりそうなこ れらの業務の特徵を見てみたい.

Figure 1 に薬剤師が OTC 医薬品の販売時に行う 相談対応手順の概略を 5 段階で示した。 OTC 医薬 品販売時の相談対応は個々の事例によって異なる場 合があり，各段階を行き来したりしてさらに複雑な 手順を踏むことがあるが，わかり易くするために概 略のみを示した．また，医薬品医療機器等法及びそ れらの関連法規には，OTC 医薬品販売時の販売方 法, 確認事項, 情報提供項目などについて多くの規 定があり，それらにも言及する必要があるが紙数の 関係もあってこれらは省いた。ここでは薬学教育を 行う上で課題となりそうな点にしぼって話を進めて いきたい。

OTC 医薬品販売時の相談対応が処方箋調剤の場 合と最も異なる点は，多くの場合，相談者は相談対 象の健康トラブル（以下「症状」）について医療機 関で受診していないので薬剤師が「ファーストアク セスかつ唯一の医療人」になることである。そのた
め，相談対応の際に薬剤師が行った助言，指導は大 きな影響力を持つ．相談者の症状がなんらかの疾病 によって発現している場合，その転機を左右する可 能性がある点である.

OTC 医薬品販売時の薬剤師の接客手順は 5 段階 で構成されている，すなわち，(1)情報収集・確認， (2)情報の分析・評価・判断, (3)OTC 医薬品の選 択・適否判断, (4)医薬品の情報提供・販売, (5)販売 記録の作成・モニタリング（アフターケア）である (Fig. 1)。これらの各段階について薬学教育におい て課題となりそうな点を中心に述べてみたい.

(1) 情報収集・確認

この段階では，まず基本的事項として症状を発症 した人（本人か否か), さらにその人の性別, 年齢 などを確認する．OTC 医薬品販売では「相談のた めに薬局に訪れた人が症状を発症した本人」とは限 らない，症状を発現した本人の代理で OTC 医薬品 を求めてきたり，常備薬や旅行などに持参する医薬 品に関する相談もしばしば持ちかけられるからであ る.

ついで，相談対象となつた症状について，発症部 
位，症状の程度・状況（質), 発症時期やその後の 時間経過，症状が増悪したり軽減したりする要因, 主訴と随伴症状，過去に同様な症状発症の経験があ るか否か，ある場合はそのときの対処と結果，妊娠 及びその可能性や授乳の有無, 医療機関の受診状況 や併用薬（OTC 医薬品を含む），健康機能食品など の摂取状況，職業や生活環境などなど様々な情報を 聞き出してゆく，前述の「(9) 要指導医薬品・一般 用医薬品とセルフメディケーション」に挙げられた SBOs（以下「改訂コアカリ一般薬関連 SBOs」）で は，主に 4 がこの段階に関係する。

(2) 情報の分析・評価・判断

この段階では，前の段階で得た情報を分析・評価 し, 症状から可能性がある疾患（病名）を推定し, 「受診勧奨が必要か否か?」を判断する。受診勧奨 を要しない場合は「OTC 医薬品が必要か否か?」 の判断をする，広い範囲の症状に対応できる医学的 知識が必要である。すなわち，改訂コアカリ，E1 薬の作用と体の変化 (2) 身体の病的変化【(1)症候】 に挙げられた各症候・病態と E2 薬理・病態・薬物 治療に挙げられた各疾患に関する知識と応用力が必 要となる．改訂コアカリ一般薬関連 SBOs では，主 に3がこの段階に関係する。もし，受診勧奨が必要 であれば受診勧奨を行い，医薬品が不要であれば適 切な健康上の助言などを行う。相談者の症状が OTC 医薬品を用いたセルフメディケーションの対 象であれば，次の段階に進んで適切な OTC 医薬品 の選択を行うこととなる．受診勧奨を行った場合で も，医療機関で受診するまでの間，一時的に症状を 軽減する目的で OTC 医薬品（いわゆる「つなぎの 医薬品」）の販売を行うこともある．また，相談者 に受診勧奨するとともに医師に対する紹介状を作成 して手渡す場合もある．医師に対する紹介状に相談 者の症状などの要点を簡潔に記述するための知識, 技能も必要になる。

(3) OTC 医薬品の選択・適否判断

この段階では, 相談者の症状や健康状態, 諸事情 に最適の OTC 医薬品を選択する。いったん選択し た OTC 医薬品は再度吟味検証して相談者に最適な OTC 医薬品であることを確認する，処方箋調剤で は，患者が使用すべき最適医薬品，すなわちその患 者にとつて最も「有効性」が高い医薬品は処方医が 選択する。しかしながら， OTC 医薬品販売の場で
は相談者に推奨すべき医薬品は薬剤師が選択するこ とになる，改訂コアカリ一般薬関連 SBOs では，主 に 2,5 及び 6 がこの段階に関係する.

前述のように，処方箋調剤では処方薬が医師に よって決められているため, 薬剂師は処方監査の 際，主に「安全性」確保の立場から処方監査をすれ ばよいが，OTC 医薬品販売の場では薬剤師は「有 効性」と「安全性」を両立できる医薬品を選択して 相談者に推奨しなければならない.

さらに, OTC 医薬品は「需要者の選択により使 用される」ため「OTC 医薬品を使用するか否か」, 「OTC 医薬品を使用するとしたら，どの OTC 医薬 品を使用するか」の決定は需要者（すなわち，相談 者）が行う。こうした点も処方箋調剤とは異なる点 である。

(4) 医薬品の情報提供・販売

次の段階では，相談者に最適の OTC 医薬品を提 示し情報提供を行って販売する。前述したように OTC 医薬品の選択は「需要者 (相談者)」が行うの で，その OTC 医薬品が相談者に最適であることが 適切に説明できて，その説明内容を相談者が納得し ないと OTC 医薬品の購入には至らない。同時に, 副作用や使用上の注意などの負の情報や相談者に注 意や配慮を喚起する情報も適切に伝える必要があ る.また，最近では OTC 医薬品の販売者を明示す るとともに，購入後の疑問や問い合わせに対応する ために販売者氏名や連絡先などを記したカード（名 刺）を交付したり，シールを貼付したりすることも 多い。また，相談者が「お薬手帳」を持参している ときは必要事項を記入する。 このような情報提供に 相談者が納得し，その OTC 医薬品を購入して服薬 する意思を示して初めて販売に至ることができる. 処方箋に書かれた医薬品が調剂されて交付され，当 然のごとく患者が持ち帰る処方箋調剤の場面とは一 線を画している．改訂コアカリ一般薬関連 SBOs で は，主に 5,6 及び 7 がこの段階に関係する.

(5) 販売記録作成・アフターケア

販売後は，相談者（患者）毎の販売記録を作成す ることが望ましい．要指導医薬品及び第一類医薬品 では販売記録の作成が法規上に定められている. OTC 医薬品販売と処方箋調剤を平行して行ってい る薬局では，両方の記録（OTC 医薬品の販売記録 と処方調剂における薬剤服用歴）がともに一元的に 
管理されることが望ましい.

販売後に相談者（購入者）から質問，問い合わせ などがあった場合は適切に対応する，万一重篤副作 用を発症したような場合では，医薬品医療機器総合 機構に対する副作用被害救済制度の申請などについ て相談者（購入者）を支援するととともに，厚生労 働大臣に所定の報告を行う。改訂コアカリ一般薬関 連 SBOs では，主に 8 がこの段階に関係する。

\section{4. おわりに}

上記の各段階を通覧すると, OTC 医薬品販売の 各段階で幅広い薬学，医学及び関連分野の知識と臨 機応変な対応を取り得る応用力が必要であることが わかる。また，改訂コアカリ一般薬関連 SBOs に は，これらの各段階で必要な知識，技能が盛り込ま れている，さらに，現場ではコミュケーション力も 必要である。情報収集の段階では，相談者に安心感 を与えて信頼関係を構築しないと的確な判断に結び つけるために必要な情報が得られない，相談者から 得た症状についての情報から重篤疾患などの可能性 を見い出して受診勧奨する場合でも，相談者を納得 させ行動を起こさせる（医療機関を訪れて受診する ように仕向ける）コミュニケーション力がないと， 重篤疾患の可能性を見い出した薬剤師の能力も受診 勧奨そのものも無駄になることとなる.

以上の点から, OTC 医薬品とセルフメディケー ションに関する薬学教育は，「医療人として高い意 識を持ち, 幅広い医学, 薬学の知識と応用力を持 ち，高度なコミュニケーション能力を備えた『ジェ ネラリスト薬剤師』を養成する教育」と言えそうで ある，現場で業務する薬剤師の多くから， OTC 医 薬品についての相談対応が薬剂師の最も難しい業務 の 1 つと言われる所以である.

これら以外に, OTC 医薬品には医療用医薬品と
は異なる医薬品としての特徵がある．医療用医薬品 と比較してみると，一般生活者が使用する医薬品と いうことで安全性の確保と誤用・乱用の防止につい て格段の配慮と工夫がされていること，広範囲の症 状に対応するため他種類の有効成分を配合した配合 剤が多いこと，同一のブランド名で多数の製品が発 売されているものがあること, 添付文書や製品の被 包（外箱）の記載が一般生活者にわかり易いように 工夫されていること，一般生活者から選択されるよ う商品の名称，外箱のデザイン，シロップ剂などの 味，外用薬（とくに塗布薬，貼付薬）の使用感など が工夫されていることなどが挙げられる．改訂版コ アカリには挙げられていないが，このような OTC 医薬品の医薬品としての特徵などについても教育内 容に取り入れていきたいところである.

平成 25 年度改訂版薬学教育モデル・コアカリ キュラムに大きく取り入れられた「要指導医薬品・ 一般用医薬品とセルフメディケーション」である が，関連する他分野の教育内容と連携を保ちながら 体系的, 統合的に教育を進めて，今後の社会の二ー ズに応えることができる卒業生，薬剤師を養成した いと考えている.

利益相反＼cjkstart開示すべき利益相反はない，

\section{REFERENCES}

1) The Pharmaceutical Society of Japan. “Model Core Curriculum for Pharmaceutical Education 2008 edition.": $\langle$ http://www.pharm.or. jp/kyoiku/>, cited 27 July, 2015.

2) The Pharmaceutical Society of Japan. "Model Core Curriculum for Pharmaceutical Education 2013 revised edition.": 〈http://www. pharm.or.jp/kyoiku/>, cited 27 July, 2015. 